a new chapter to the topic. He did not recant, however, but persisted in his conclusion - that because clinicians saw the body as a machine, whose disorders could be put right in the same way as a car repair, they had overlooked the enormous contribution from modifying disease origins. Moreover, because the role of some influences had been overemphasized (particularly medical care), society had misused its resources and needed to reconsider how such resources were allocated.

In his new book, completed just before he died in June of this year, McKeown classifies human existence into three phases. In the first (hunter-gathering) apart from accidents and tribal wars the important restraints on population growth were infanticide and malnutrition/starvation. The food supply increased 5,000 years ago during the second phase (agriculture), but again the benefits were outstripped by population growth, and malnutrition recurred. And then another predominant cause of illness and death arrived: infectious diseases. Probably originating from animals (measles from dogs, the common cold from horses, tuberculosis from wild cattle, plague from gerbils and influenza from pigs), they could become established and amplified not only against the background of malnutrition but because people now lived together in larger communities, under cramped conditions with poor hygiene.

In the West, the third phase (industrialization) began three centuries ago. Health standards and nutrition dramatically improved, while the population rose and has continued to do so - staggeringly so for the whole world ( 750 million in 1750 , two (American) billion in 1930, five billion today, with probable stabilization at ten billion in 2100). In McKeown's view the early increase in Western populations owed everything to better nutrition, which increased resistance to the infectious diseases, the increase in the late 1800 s also being linked to better hygiene (piped water, sewage and safe milk). Further, communities came to limit their reproduction using contraception, and infanticide disappeared once most children were wanted. Significant medical advances arrived only in the twentieth century, particularly emergency surgery, chemotherapy for puerperal fever and tuberculosis, and immunization against diphtheria and poliomyelitis.

For the individual these and other later developments were obviously important - but, for populations, their role was minor compared with that of better nutrition and bathrooms. Now, however, modern life has produced its flip side: the non-communicable diseases, which, given that human genes have remained unchanged and that these illnesses were absent in wild animals, hunter-gatherers and agriculturalists, McKeown calls diseases of maladaptation. These diseases originate in the environment, through changes in diet (too little fibre and too much food, salt, fat and sugar); the use of alcohol, tobacco and illicit drugs; lack of exercise; and pollution.

One can argue with some features of McKeown's thesis: he is uncritical, for example, about 'bran-wagon' evangelism that explains everything from coronaries to varicose veins as being the consequence of too little dietary fibre. Similarly he surely underplays the value of modern drugs, such as the antibiotics, in prolonging useful and fulfilling life. But in global terms he is right. In future centuries even the West's current spectre, AIDS, will figure as only a blip on the population screen, comparable with the 'minor' effects of bubonic plague or the influenza pandemic - how could we conclude differently in a world where five million children under the age of five still die from diarrhoeal diseases every year?

But the great merit of McKeown's book is that it points to solutions within our grasp. If sufficient food was available to every citizen in the underdeveloped world, health and self-limitation of the population would follow. This approach has worked in China, Sri Lanka and Kerala, where, through the political will to attain equality in health, Western standards have been achieved without improving water quality, sanitation or personal health services (including immunization). As N.H. Antia wrote recently (Nature 335, 584; 1988): "Vaccines . . . should not divert [Indian] attention from the major problem - the need for egalitarian socioeconomic development that alone can eradicate the root cause, namely poverty".

The developed world should recognize that diseases, including the noncommunicable ones, are not inevitable. Action is indeed being taken, from the top downwards. Abolishing cigarettes would eliminate one in three deaths from cancer and smoking is fast becoming unacceptable. The same will happen with excessive alcohol consumption, and in eliminating the $3 \mathrm{lb}$ of chemicals we eat in our food every year. Nevertheless, the developed world has not abolished diseases of poverty; the greatest contribution to health would come from ridding our society of inequalities, which, as the Black Report showed, are still a blot on most countries. And, as McKeown himself wrote some ten years ago: "If a choice must be made, free school meals are more important for the health of poor children than immunization programmes, and both are more effective than hospital beds".

Stephen Lock is Editor of the British Medical Journal, BMA House, Tavistock Square, London WCIH 9JR, UK.

\section{Man and microbe}

\section{Christopher Lawrence}

Robert Koch: A Life in Medicine and Bacteriology. By Thomas D. Brock. Science Tech Publishers, 701 Ridge Street, Madison, Wisconsin: 1988. Pp.365. \$35. Distributed outside North America by Springer-Verlag, $£ 17$.

UNTIL now there has been no book-length biography in English of the German bacteriologist Robert Koch. Indeed, as the author of the present volume notes, "even the German language biographies of Koch are dated and mostly inaccessible" (p.vii). This biographical void is perhaps partly related to Koch's authoritarian personality and his less than impeccable marital life when measured by the standards of the later nineteenth century. Nonetheless it is still surprising because Koch's life contains nearly all of the elements a scientific biographer might wish for: an earth-shattering discovery by a young, unknown and solitary doctor, a rapid rise to fame (and shame), a medical revolution and more than a hint of sexual intrigue.

Koch was born in lower Saxony in 1843 . After a conventional medical education and an unremarkable bourgeois marriage he settled down in 1872 as District Medical Officer in the town of Wollstein, now in Poland. The 1870 s were a turbulent decade in European medicine. The advocates of laboratory science were just beginning to turn the tide against the bedside men, and the proponents of a germ theory of disease were making their voices heard against the defenders of miasma or atmospherical pollution. These two controversies were related. By 1900 bacteria seen through the microscope on the laboratory bench had become the symbol of a new and scientific medicine.

Koch worked in an area where anthrax was rife. For a general practitioner, he was exceptionally well read in the medical literature and, more surprisingly, he was an exceptionally devoted experimentalist. After many months of painstaking research Koch convinced himself that anthrax was caused by a living organism and, more important, that this organism could survive as spores in the soil and in animal hides. Convincing himself was one thing, however. What about the world?

In April 1876 the provincial doctor took his preparations to the illustrious botanist Ferdinand Cohn and the great pathologist Julius Cohnheim at the University of Breslau. Both men were sympathetic to the germ theory and immediately championed Koch's work. From this point Koch entered a much larger public arena. He moved to Berlin and over the next ten years he and his collaborators created many of today's basic bacteriological tech- 


\section{Metastic Spread of Cancer \\ G.V. Sherbet}

This book outlines a new approach to the analysis of the mechanisms of metastasis by comparing the glioma, an intracranial tumour which ordinarily does not metastasize, to other metastasizing tumour models. This has produced a coherent picture of the operation of oncogenes and growth factors in the initiation, development and progression of neoplasms.

This is an essential book for those researching metastasis and will be of interest to all research oncologists.

$1987 \quad \mathbf{f} 45.00 \quad 275 \mathrm{pp}$

234x156mm 0333443624

\section{Contents}

\section{Part 1}

Introduction

The Intrinsic Malignancy of Gliomas

The Metastatic Cascade

\section{Part 2}

Heterogeneity of Tumours

Oncogenes in Tumour

Development and

Metastasis

The Genetic Instability of Neoplasms

The Generation of the Metastatic Phenotype

\section{Glossary}

References

index

Order this book through your bookseller or send your order to.

Richard Gedye, Macmillan Press Ltd, Houndmills, Basingstoke RG21 2XS, UK.

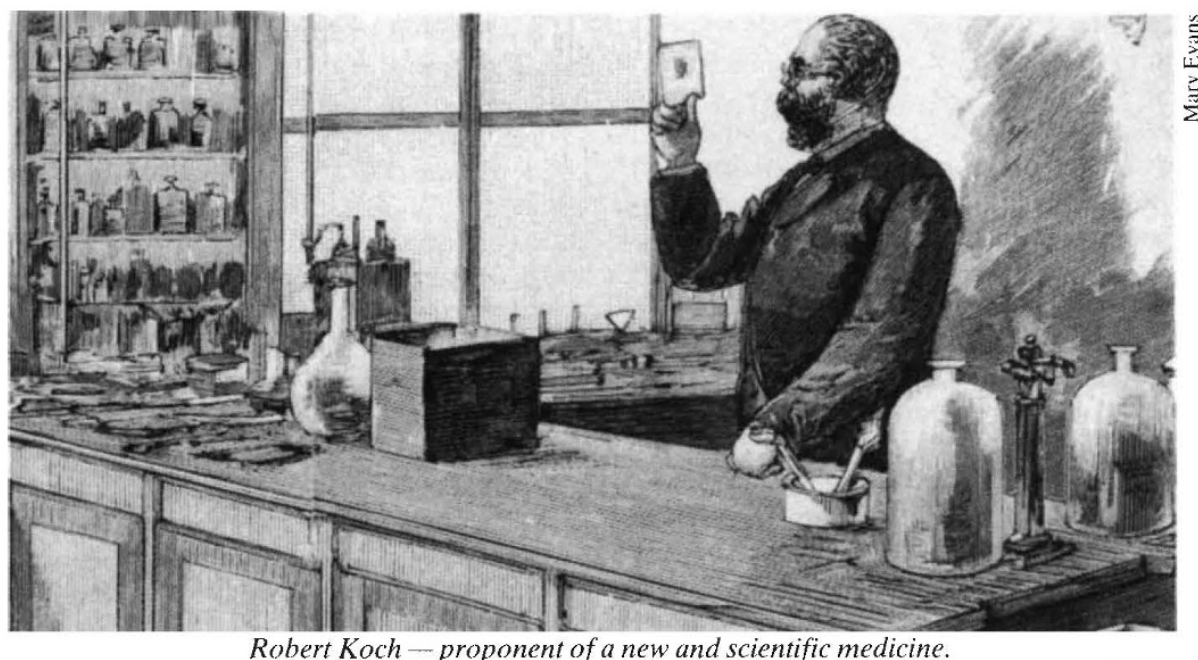

Robert Koch - proponent of a new and scientific medicine.

niques. Koch's greatest public moment came with his announcement of the discovery of the tubercule bacillus in 1882 . In addition he described the cholera vibrio and it was his co-workers and students who identified the bacteria responsible for many of the killer and crippling diseases of the nineteenth century, such as diphtheria, gonorrhoea and plague.

Thomas Brock relates all of these matters, although most of them would merit a small monograph in themselves. The biography is of a conventional sort; the Koch presented here is the one who was known from previous smaller and less satisfactory accounts. Brock gives us Koch and his warts in some detail, including Koch's famous announcement of his discovery of tuberculin as a cure for TB, his disputes with Pasteur and various other European men of science, his domineering character and competitiveness, the collapse of his first marriage and his remarriage when aged 50 to a 20-year-old art student (with whom he had had an affair since she was 17). Brock is perhaps cunningly trying to evoke our sympathy here by juxtaposing a photograph of the (to us) stern and matronly Emmy Koch (his first wife) with one of a sylph-like Hedwig Frieberg as she was when she first met Koch.

Although it is over 350 pages, this is not a long book. The illustrations, the short chapters and the layout combine to make it less extensive than it appears at first sight. The substance of the text also fails to confirm the first impression that this is a thorough reassessment of Koch's life and work. Brock offers no re-evaluation of previous work, nor do current trends in the history of science enter his interpretation. For him, Koch's discoveries were unproblematic pictures of nature which, willy-nilly, the world was obligated to accept.

Such an approach allows Brock to duck issues which otherwise his material would force on him. Thus when one of Koch's coworkers swallows a culture and develops cholera it proves that the disease was caused by the vibrio. When Pettenkofer swallows a similar culture with no effect it merely proves he was lucky and Koch was right anyway. Similarly, Koch is praised for patience and faith when persisting with seemingly unfruitful experiments, while his opponents are accused of stubbornness for doing the same thing. (Koch himself, however, is called pig-headed for sticking to his views on the non-communicability to humans of bovine tuberculosis.)

Nonetheless, the strengths of this enjoyable book outweigh its weaknesses. It is readable and not too demanding. Although the author is a microbiologist he does not get carried away with technical questions, and for the non-bacteriologically minded explains his material lucidly. He gives us something of Koch the man, he has read the German material and quotes from a number of letters. The account is also decorated by letters from visitors, such as Arthur Conan Doyle, to Koch's Berlin empire. Brock is at his best in setting Koch's technical innovations in context. Here, in spite of all the talk of discovery and breakthrough, he shows that the establishment of bacteriology had less to do with claims about causality than the capacity of bacteriologists to repeat practical everyday tasks and, with their technology, to demonstrate their account of the world.

There is one wider question, however, which is not touched on at all, or at least only to endorse conventional wisdom. This is Brock's view that "to a real extent we owe our current good health and longevity to discoveries made by Robert Koch and his school". Against this it might properly be argued that, since antiquity, society has known about the healthpromoting value of fresh water, a varied diet, clean air, good housing, exercise and relaxation. The politics of implementing these for everybody, rather than the difficulties of discovering bacteria, might be said to have been the biggest obstacle to our Western well-being.

Christopher Lawrence is at the Wellcome Institute for the History of Medicine, 183 Euston Road, London NW1 $2 B P$, UK 